\title{
HERESY AND FORFEITURE IN MARIAN ENGLAND*
}

\author{
P. R. CAVILL \\ Pembroke College, University of Cambridge
}

\begin{abstract}
The work of the martyrologist John Foxe ensures that the burnings dominate modern accounts of the campaign waged again Protestantism in the reign of Mary I (15538). Drawing on other sources, this article examines forfeiture of property, a less noticed but more common penalty imposed upon Protestants. It describes the types of forfeiture that occurred and analyses their legal basis; it considers the impact of the penalty and highlights means of evasion. By examining forfeiture, the article extends and enhances the debate about the effectiveness of Marian religious policy and about the degree of support that the regime could command. Forfeiture, it is shown, could be a powerful form of coercion, but depended upon popular politics to be effective. Subsequent efforts in Elizabeth I's reign to obtain restitution substantiate the article's thesis that a deep-rooted belief in the rule of law constrained the penal religious policies of early modern England.
\end{abstract}

The burning of 284 Protestants continues to exercise a strong grip on historical writing on Mary I's reign. Concentration on the burnings, however, distorts our understanding of the regime's religious policy and of Marian Protestantism. The prominence of the burnings testifies, above all, to the enduring power of John Foxe's vision and to his immense industry. First published in 1563, the Acts and monuments towers over all other sources for Protestantism under Mary. ${ }^{1}$ Modern scholarship has moved away from a confessional concern with Foxe's accuracy as a chronicler of persecution towards subtler analyses of the work's research, composition, and revision. A tension exists between our deepening appreciation of the Acts and monuments as the intellectual and physical product of the 


\section{P. R. CAVILL}

Elizabethan church and its discontents, and our continuing reliance upon this work as a guide to Mary's reign. ${ }^{2}$ The idea that the burnings were counter-productive, alienating the people from the regime, may have originated with Foxe. ${ }^{3}$ While recent reappraisals have challenged this view, they too depend on reading Foxe's evidence, albeit against the grain. ${ }^{4}$ Hence even these revisions cannot wholly escape Foxe's framework. Therefore this article seeks to decouple Foxe from Marian Protestantism. While it cannot avoid drawing on the Acts and monuments, the article reads Foxe alongside other sources and tries not to let his parameters prejudge the terms of the debate.

Martyrdom dominated Foxe's account of Mary's reign. The Acts and monuments divided the reign into four parts: an account, by far the largest, of those burnt; a briefer discussion of those who suffered corporal punishment; another short section on those who narrowly escaped danger; and a report of the sudden, gruesome, or desperate deaths of individual persecutors. ${ }^{5}$ Exile, Foxe's own experience, received only glancing comment. Punishments less spectacular than burning were also marginal to his account of Protestant suffering. In particular, the Acts and monuments touched only in passing upon forfeiture of property, usually in order to underline the cruelty of individual persecutors. Forfeiture can, however, be studied through other sources that are seldom used by historians of religion: administrative records that were not seeking to document Protestant suffering but did so incidentally, and which remain in manuscript. Many such sources are found in the archives of central government: principally, inquests into heretics' estates, accounts of sheriffs and escheators (royal officers who administered the crown's prerogative rights), and legal cases arising from forfeiture. Other sources come from local records relating to individual manors and towns, where much scope remains for further research. Of course, it is not being suggested that such supposedly neutral sources should be treated as antidotes to Foxe. Rather 


\section{HERESY AND FORFEITURE}

it is proposed that, by revealing dimensions of the subject that Foxe overlooked, these sources prompt alternative ways of thinking about Marian Protestantism.

The article begins by analysing how the laws relating to forfeiture applied to Protestants. Unlike burning, forfeiture affected not only martyrs, but also continental exiles and internal refugees. A focus on forfeiture helps to refine the taxonomy of Protestantism: labelling those who lived through Marian England conformists flattens out the contours of their experience. While confiscation of property did not deter the martyrs or the continental exiles, it appears to have been more effective against others in England. The second section explores how the martyrs, their families, and supporters responded to the threat of forfeiture. The evidence here points to avoidance, rather than evasion, of the penalty: that is, attempts to protect property within the legal framework governing the administration of forfeiture, rather than extra-legal concealment (which, however, is less likely to have been recorded). The activities of those neighbours, trustees, and prison visitors who mitigated the impact of forfeiture imply a degree of sympathy for the prosecuted. While they may yet have differed over religion, many seem not to have viewed committed Protestants of their acquaintance as detestable heretics to be ostracized. The third section examines forfeiture as the interaction between local communities and central government through a case-study of the county of Essex. Individual magistrates were probably important in making forfeiture an effective penalty. Some local officers, manorial jurors, and neighbours may have obstructed the imposition of the penalty or have acted for personal gain; clearly, others did not. Some inhabitants behaved in a seemingly paradoxical way: defending the property rights of those whose religion they rejected.

This last discovery suggested to me an alternative interpretation of the evidence that diverged from the increasingly unhelpful paradigm of support versus obstruction bequeathed by Foxe. Scholarship on the Reformation often invokes a 'culture of obedience' in order to 


\section{P. R. CAVILL}

explain why the majority did not resist religious policies that may have been unpopular. ${ }^{6}$ This concept of obedience can imply a passivity or inertness at odds with what else is known about sixteenth-century political consciousness. ${ }^{7}$ The idea of 'mere' obedience may also leave the actual content rather under-analysed: obedience to whom, to what purpose, and within what limits? In an important insight, obedience has been redefined in a way that emphasizes participation in governance over acquiescence. The enthusiasm with which ordinary people 'collaborated', it is maintained, matters less than the fact that they did so. ${ }^{8}$ The idea is valuable in interpreting forfeiture because the penalty depended not only on an elite magistracy but also on ordinary people acting as local officers and inquest jurors. In this model, an individual's rational self-interest has pride of place as a motivation. In the case of forfeiture, the potential for profit existed for the crown, for grantees of confiscated estates, for lords to whom tenants' lands reverted, for corrupt administrators, and even for discreet neighbours. ${ }^{9}$ But financial interest seems insufficient as an overall explanation for the conduct of the crown or others. Above all, profit fails to explain the selective application and circumscribed imposition of the penalty.

The article therefore makes the case for conceiving of obedience in terms of lawmindedness. This conception retains the idea that participation and approbation were distinct, but replaces the potentially anachronistic idea of the rational individual acting in his or her best interests with one that seems more historically rooted. Forfeiture occurred within, and was justified through, a framework of legal rules and processes: what we might call the rule of law. Granted, the rule of law was hazily defined, admitted discretion, could cause disobedience (as in 1536), and co-existed with a dislike of the legal profession. ${ }^{10}$ Nevertheless the central idea of the law as guardian of property rights makes sense of the evidence presented here. Common law informed political thinking across society, and the break with Rome probably intensified this element in English culture. ${ }^{11}$ Unlike mere 


\section{HERESY AND FORFEITURE}

conformity or passive obedience, law-mindedness did not always favour royal interest. In July 1553 support for Mary's accession beyond her own affinity probably owed more to a legitimist defence of her inheritance than it did to religious preference. ${ }^{12}$ Yet the Marian regime's inability to force laymen to restore former church lands also upheld the sanctity of property rights. ${ }^{13}$ The article's fourth section hopes to clinch this case by showing how lawmindedness cut across confessional boundaries. Notwithstanding the dramatic about-turn in religion, in Elizabeth I's reign legal principles circumscribed attempts to recover property that had been confiscated under Mary. Thus the subject of forfeiture in Mary's reign turns out to have implications for the enforcement of religious uniformity in early modern England in general.

The term 'forfeiture' needs defining. In its original sense, it denoted the breaking of a law etymologically, a misdeed. By transference, the term also applied to the penalty for an offence. Now, its only standard, non-specialist sense refers to the fact of losing something (commonly property) as a consequence of a crime or other transgression. Although 'forfeiture' is used in that modern, capacious sense in this article, contemporaries would have been more fastidious. They drew several distinctions: between dispossession as a consequence of conviction for a capital offence and as a punishment directly imposed, more like a fine; between confiscation based on common law or on statute law; and between permanent deprivation and distraint, the reversible seizure of chattels in order to make a person meet an obligation. They would also have differentiated loss of real property (land) and personal property (goods and chattels): in the former case, they might have preferred the term 'escheat', denoting the reversion of land to the feudal lord when a tenant died without legal heirs. In its broad sense, forfeiture, unlike burning, was a common penalty in sixteenth- 


\section{P. R. CAVILL}

century England: it was imposed on traitors, murderers, and other felons, and also on fugitives from justice. ${ }^{14}$ Protestantism itself was not punishable by forfeiture, yet Protestants suffered forfeiture. Categories of offence, rather than of belief, determined who did and who did not suffer forfeiture. Forfeiture affected three types of religious dissident: rebels and conspirators; fugitives, both overseas and within the realm; and those convicted of heresy. Although subsequent sections will concentrate on those convicted of heresy, here each category of offender is discussed in order to emphasize the breadth of forfeiture as a punishment. Most accounts of Marian Protestantism focus on either the martyrs or the continental exiles: examining forfeiture substantiates the argument that Marian Protestantism was a more diverse phenomenon. ${ }^{15}$

Religion motivated many of those who were convicted of treason, even if they were denied the status of martyr. ${ }^{16}$ The regime's propaganda rehearsed the commonplace symbiosis between heresy and treason. ${ }^{17}$ The usurpation of Lady Jane Grey ensured that Mary's reign started with extensive confiscation of the goods of traitors; Thomas Wyatt's rebellion in 1554 and Henry Dudley's conspiracy in 1556 produced further forfeitures. ${ }^{18}$ The privy council oversaw the inventorying of the assets of such high-status and wealthy offenders. ${ }^{19}$ Treason was punished by a uniquely severe form of forfeiture. Unlike in cases of heresy and felony, both real and personal property was forfeit exclusively to the crown; moreover, confiscation extended to lands which the offender had held in fee tail (a restricted form of descent) and also to those lands that were held by others in trust. ${ }^{20}$ Yet the regime also mitigated the rigours of forfeiture, partly in deference to the standing of the offenders' families. In 1553 the duchess of Northumberland, the marchioness of Northampton, Lady Gates, and even Mrs Cranmer received some of their husbands' effects. ${ }^{21}$ This moderation also enabled the reconciliation of political offenders, such as Sir Peter Carew or Sir Nicholas Throckmorton. ${ }^{22}$ By contrast, most of those executed for heresy rather than for treason were 


\section{HERESY AND FORFEITURE}

'the more simple \& inferior sort of people', whose families were thus ineligible for this socially and politically selective grace. ${ }^{23}$

In the cases of high-profile traitors, the crown's financial interest appears of paramount importance. The detailed inventories reveal the extent to which royal ministers and courtiers, their servants, and favoured nobles also benefited, for these books are full of annotations recording the purchasing or receiving gratis of individual items. ${ }^{24}$ The possessions of convicted heretics, however, usually escaped the direct scrutiny of central government, in part because the victims were worth little. Realizing the potential value of their forfeited estates normally depended on the routine work of county officers, whose diligence and probity varied. ${ }^{25}$ Cash-strapped mid-Tudor governments pinpointed the system's weakness, without being able to reform it. ${ }^{26}$ The revenue commission of 1552 found that the previous year's profits from felons' goods amounted nationwide only to $£ 60$. Such forfeitures were casualties, that is, occasional revenues which officers 'are charged therewith upon their own confession'. ${ }^{27}$ A system of account whereby an officer became liable for what he chose to declare discouraged initiative and lay wide open to corruption. Thus the crown issued special commissions in cases where confiscation was significant, either for profit or for policy. These cases included the continental exiles, for whom forfeiture was not the consequence of attainder for a capital offence, but rather a specifically targeted punishment in its own right.

Foxe responded to the restoration of Catholicism by fleeing abroad, and estimated that almost a thousand people had done likewise. ${ }^{28}$ Having initially permitted or even encouraged Protestants to leave, the regime attempted to reverse the exodus. A bill before parliament in October 1555 would have confiscated the lands of emigrants. Its defeat in December reflected religiously motivated opposition, but also concerns about the liberty of subjects to depart the realm with their property and not to be punished through retrospective legislation. ${ }^{29}$ The 


\section{P. R. CAVILL}

crown thus turned to a statute of 1382 that arguably permitted the seizure of goods and chattels (including leases), but not lands. ${ }^{30}$ Also, in justification, the crown pointed to a proclamation issued by Edward VI's council that had imposed the same penalty for this offence. $^{31}$ (Religious exiles - such as Dr John Clement, formerly tutor to Sir Thomas More's children - had indeed suffered forfeiture in Edward's reign.) ${ }^{32}$ The crown sent messages overseas commanding particular individuals to return. ${ }^{33}$ Those who refused were in breach of their allegiance, so - royal counsel maintained - their lands too might be seized. ${ }^{34}$ Without statutory underpinning, however, the legal position on exiles was uncertain. Through an assemblage of precedents, the Marian regime achieved its ends in a way that resembled good law. From the government's perspective, the rule of law was thus flexible enough and favourable enough to the crown's interests to suit its purpose, while also conferring a legitimacy on royal actions that seizure alone could not. ${ }^{35}$

The crown appointed special commissions to identify fugitives and their property. The earliest known commission sat at London's guildhall on 28 February 1555 . The jury named forty-three former residents of the capital - leading clergymen, merchants, and craftsmen who had left the realm between 11 October 1553 and 10 February 1555. On 9 November 1555 the regime ordered the seizure of their personal property. ${ }^{36}$ The most striking feature of the presentments was the inaccuracy of the given dates of departure. The former bishop of Exeter Miles Coverdale was described as having fled on 1 May 1554; he had in fact been licensed to leave on 19 February $1555 .{ }^{37}$ The tailor Adrian Artham successfully contested his presentment: supposed to have fled the London parish of St Michael Bassishaw on 1 March 1554, he had been residing in another parish, St Michael Crooked Lane. ${ }^{38}$ Yet Artham had left a well-stocked house, so perhaps he had fled and then returned to the capital. John Curteyne challenged the presentment of his brother-in-law Peter le Gashe, a skinner from Clerkenwell. Le Gashe did not flee on 2 November 1553, Curteyne pleaded, but remained a 


\section{HERESY AND FORFEITURE}

resident until 1 March 1555, one day after the commission had sat. On 9 December 1554 le Gashe had given his property to Curteyne and his wife, however, so he was contemplating flight. The fact that it was Curteyne who pleaded on 10 February 1556 suggests that at some point le Gashe did indeed leave. ${ }^{39}$ The success of Curteyne's claim illustrates how observance of legal process may have hampered efforts to apply pressure to fugitives.

Special commissions are among the worst-documented processes of sixteenth-century government, to which the fugitives commissions prove no exception. We do not know how many commissions were issued or what regions they covered. Uniquely, the returns for the commissions covering two-thirds of Essex in September 1556 have survived. ${ }^{40}$ Unlike the London commission, these commissions identified those who had fled elsewhere within England as well as overseas. On what legal basis the crown seized the personal property of those remaining in England went unstated. Although indicted fugitives and outlaws forfeited their goods, those identified were not necessarily subject to any legal process. Technically, the commissions were only enabling the subsequent distraint of property: hence one presentment was cancelled when the couple returned home. As Bishop Bonner's agent explained, property was seized so that 'the owners should haue neither vse nor commodity thereof, but by Inuentory remaine in safe keeping, vntill the cause were determined' ${ }^{41}$ The Essex commissions found that, of the seventy-four individuals identified, sixty-five had fled elsewhere within the realm. Internal refugees may therefore represent the largest of the groups who suffered seizure of property. Yet - because the sources are so sparse - their experience barely features in existing accounts of Marian Protestantism: it deserves greater prominence.

Foxe might have written much more about exile, both within England and overseas. The first edition of the Acts and monuments of 1563 commented on the 'infinit nomber' of people forced to flee and thus despoiled of their possessions, of whom it identified around 


\section{P. R. CAVILL}

seventy. ${ }^{42}$ But this chapter was omitted from subsequent editions, which in other respects expanded earlier material. Further, a commission provided only a snap-shot of what must have been a wider dispersal, so in order to discover more the records of individual communities have to be searched. Judged 'out of ordre' by the privy council, the Sussex parish of Rotherfield produced one martyr but several fugitives. ${ }^{43}$ In October 1556 three residents fled following their presentation for heresy before the commissary court of the bishop of Chichester. Their reappearance at the manor court in March 1558 implies that two subsequently had conformed. ${ }^{44}$ In Suffolk in 1556 twenty-one inhabitants of Mendlesham were reportedly expelled from the town; yet three of them later attended one of the town's manor courts (in 1557 John and William Duncan and in 1558 Thomas Hobard). ${ }^{45}$ Had they also now conformed? Driven from his curateship at Hadleigh (Suffolk), Richard Yeoman was reduced to peddling in Kentish villages to support his family. ${ }^{46}$ In other cases, outside Foxe's martyrological remit, deprivation of home, livelihood, and possessions may have proved an effective form of coercion.

Focusing on internal refugees therefore challenges the taxonomy of Marian Protestants as either (overseas) exiles, or martyrs, or conformers. The evidence of forfeiture highlights instead the grey area between the martyrs' defiance and thorough-going dissimulation. ${ }^{47}$ Categorizing Protestants in England as conformists may lean too uncritically on contemporary anti-Nicodemite writing. ${ }^{48}$ Certainly, this label prejudges an issue about which little, in fact, is known. ${ }^{49}$ In order to justify their own conduct, continental exiles emphasized that they too suffered a form of martyrdom. By stressing the material losses that resulted from flight overseas, their writings depreciated the experience of fellow believers remaining behind in England, who were presumed to be unwilling to endure such privations. ${ }^{50}$ The hardship of those Protestants who survived Marian England was thus marginalized, and is still easily overlooked. 


\section{HERESY AND FORFEITURE}

Neither fugitives nor traitors suffered forfeiture for heresy, which was in English ecclesiastical and common law a discrete crime with its own punishments. Based on canon law, forfeiture for heresy applied across Europe, but in ways that varied depending upon the ecclesiastical and political structure of each state. In England, forfeiture was administered by the crown, and neither concerned nor profited the church. ${ }^{51}$ In the pre-Reformation period, excommunication had not routinely resulted in forfeiture, but rather - if the offender remained defiant - to arrest, through signification by the bishop to chancery and then the sending of a writ de excommunicato capiendo to the sheriff. ${ }^{52}$ An instance of forfeiture on grounds of excommunication for heresy has, however, been identified, when in 1555 or 1556 the sheriff of Surrey and Sussex, William Saunders, seized goods belonging to John Smith of Dallingridge and unnamed others. ${ }^{53}$ Smith and nine others were the subject of a signification of excommunication for non-appearance to answer charges of heresy issued by Bishop Day of Chichester. ${ }^{54}$ Three men from Rotherfield named in the signification seem later to have conformed, for they were dwelling there by $1557 .{ }^{55}$ A vigorous opponent of Protestantism, Saunders, being unable to lay his hands on the bodies of those named, perhaps seized their assets instead. ${ }^{56}$

The old heresy laws had provided two ways in which those convicted might be punished through their possessions. Better known for authorizing burning, the statute of 1401 also allowed bishops to impose a discretionary fine upon conviction. ${ }^{57}$ Revived in January 1555, this law may have informed the power of fining granted in the heresy commission of February $1557 .{ }^{58}$ In 1559 the Elizabethan regime instructed the proctors of the court of arches to pay over 'all suche sommes of money as remayne in their handes of suche fynes as were levyed of dyvers personnes in the tyme of the late Quene by order of the Bishop of London and other Commyssyoners for examynacion of heresyes and other misdemeanours in the Churche' ${ }^{59}$ One proctor, Robert Warmington, responded that the sums raised had already 


\section{P. R. CAVILL}

been paid to officials, except for the outstanding amount of $£ 81 s 8 d$, to which he felt entitled as a (rather meagre) reward. ${ }^{60}$ Unfortunately, the list of fines that Warmington enclosed with his letter has not survived. The commission's work indicates how the prosecution and punishment of religious dissent extended beyond Foxe's martyrological remit. The evidence reinforces the case already made for the complexity of the Marian Protestant experience.

Forfeiture, as opposed to a fine, had become the punishment for obstinate or relapsed heretics under a statute of $1414 .^{61}$ Also revived in January 1555 , this statute provided the legal grounds under which the property of those burnt was confiscated. The statute circumscribed what was forfeit, to whom it was forfeit, and when it was forfeit. Goods and chattels were forfeit to the crown. Thus Sheriff Saunders seized the personal property of the four men burnt at Mayfield in September 1556, and then paid the sum of $£ 30$ - the combined value of their property and that of those named in Bishop Day's signification - into the exchequer. ${ }^{62}$ The crown commonly granted out its right to the personal property of felons, fugitives, and outlaws within particular manors and other lordships. ${ }^{63}$ Heretics were seldom named in these grants, and thus strictly fell outside their terms. Unusually, in 1554 the earl of Arundel received as a reward for aiding Mary's accession a grant of the goods of heretics, traitors, and murderers within the honour of Arundel and his hundreds. ${ }^{64}$ Those boroughs and cities whose charters permitted them to exclude sheriffs and escheators may have collected heretics' goods and chattels; if so, they do not seem to have passed the profits on to the crown. $^{65}$

The statute of 1414 had also extended forfeiture to freehold land. Land held in fee simple (that is, freehold land that could be disposed largely without restriction) was forfeit, as also applied in cases of felony. Of such land, the crown was entitled to claim year, day, and waste, after which it escheated (that is, reverted through lack of legal heirs) to its immediate lord. ${ }^{66}$ Sometimes, the crown was also the immediate lord, which explains why land forfeited 


\section{HERESY AND FORFEITURE}

for heresy appeared in a commission of sales appointed in $1556 .{ }^{67}$ Copyhold land (that is, land held according to the custom of an individual manor) also escheated in cases of felony, and hence of heresy, to the lord of whom it was held. Thus on 14 December 1557 Rotherfield's court book noted the conviction and execution in June of a tenant, Alexander Hosmer, who had held about sixty acres of customary land. On 8 December the lord of the manor, Henry Neville, Baron Bergavenny, agreed to grant Hosmer's land to another tenant, who was formally admitted the following March. ${ }^{68}$ Therefore, unlike in cases of treason, forfeiture concerned other parties besides the crown; consequently, the behaviour of lords and jurors in manorial courts is relevant in understanding the penalty's practical effect. Finally, the statute provided that seizure was to take place only after death. Some Protestants were well aware of the degree to which the statute limited the scope of forfeiture, and sought to exploit that fact in order to protect their property.

\section{II}

The impression that other Protestants were faint-hearted conformists owes much to the contrast implicit in the martyrs' self-representation. The martyrs' exhortatory prison letters rejoiced in affliction: 'Shame, imprisonment, losse of goods, and shedding of our bloud, be the iust price' paid to encounter God. ${ }^{69}$ Jesus had advised the rich young man to sell everything and follow Him, yet most imitated that young man who for love of wealth had ignored Christ's advice. ${ }^{70}$ Nicholas Ridley grieved that a fear of loss of goods had caused many to 'do in the sight of the world those thinges that they know and are assured are contrary to the wyll of God' ${ }^{71}$ Such a one was Richard Denton who, reminded of his duty by a gift from the recently executed William Wolsey, regretted 'alas I can not burne'; but burn he did in a house fire while trying to rescue his possessions. ${ }^{72}$ John Ardeley and John Simpson declared themselves 'content willingly to yeelde to the Queene all their goodes and 


\section{P. R. CAVILL}

landes' if they were permitted to practise true religion. ${ }^{73}$ Crass persecutors and uncomprehending family and friends mistakenly presumed that money or an inheritance

could move a martyr. ${ }^{74}$ Such offers were spurned: a Surrey carpenter, Thomas Iveson would not recant for all the goods in London. ${ }^{75}$ Judas-like, James Abbes repented taking money to betray Christ, returned the sum to Bishop Hopton, and duly suffered. ${ }^{76}$ Transient prosperity could not compare to everlasting bliss.

Yet the martyrs' indifference to worldly wealth tells only part of the story because they wished also to provide for their families. Laurence Saunders did not deny that responsibility when he wrote to his wife from prison that 'riches haue I none to leaue behynde mee, wherewith to endow you after the worldly maner. But that treasure of tasting how sweete Christ is vnto hungry consciences ... that I bequeath vnto you'. ${ }^{77}$ Dispensing spiritual counsel from prison, John Bradford advised, 'dispose your goodes, prepare your selues to tryall', either by standing fast or by taking flight. ${ }^{78}$ Families could be protected from the consequences of conviction by depriving the crown and others of forfeitures. It has long been recognized that fugitives took steps to protect their property from seizure. ${ }^{79}$ For instance, John Wield, 'fearyng the cruell procedynges of somme that at that tyme as he [thought] sought his distruccioun for his Relygyoun and myndyng to prouyde somme staye for the relief of his wief and Chyldrene', created a trust of his land in Writtle (Essex). ${ }^{80}$ That Foxe's martyrs behaved similarly should not detract from their religious motivation. Instead, this evidence strengthens the interpretation that insists - against a modern presumption of fanatical recklessness - upon martyrs' rational seriousness and determination of intent. ${ }^{81}$

At Mary's accession, Hugh Latimer's prominence made him a marked man. Having attended Edward VI's funeral on 8 August 1553, Latimer withdrew to Baxterley in Warwickshire, from where he would be summoned to London in September. On 20 August 1553 Latimer gave away all his personal property to his niece Mary Glover's children, Hugh, 


\section{HERESY AND FORFEITURE}

Anne, and Marmaduke. Mary's husband Robert was convicted of heresy at Lichfield on 31 August 1555. On 12 August 1555 Robert too had given away his goods and chattels, to his brother-in-law Hugh Borowes and to a draper of the city, Edmund Brodenhill. Both men had thus divested themselves of ownership before the legal point of forfeiture, the moment of conviction. Robert Glover's grant, although made in custody, was nevertheless accepted as valid, and the inquisitions into his and Latimer's property took place only after their executions. $^{82}$

Legislation authorized and also regulated the prosecution and punishment of heresy. Some Protestants studied the statute book in order to challenge the lawfulness of their detention; others exploited the loopholes that it had created. ${ }^{83}$ Under the statute of 1414 , only freehold lands held in fee simple were forfeit. Among those executed in the last year of Mary's reign Thomas Bainbridge of East Tytherley (Hampshire) was unusual in being a member of the gentry. Convicted on 28 May 1558, Bainbridge was burnt at Winchester on 6 August. Through a use created on 26 April, Bainbridge, who was unmarried, had granted the reversion, if he died without male issue, of his manor of Lockerley Butler and other lands to his kinswoman Anne Gifford and her husband Richard of neighbouring King’s Somborne. Thereafter Bainbridge held the lands in fee tail (akin to an estate for life), rather than in fee simple. Bainbridge's execution extinguished his interest and hence the forfeit: no land escheated. $^{84}$

If seizure observed the terms of the statute, then we might wonder how any property could have remained to be confiscated, for no crime was more premeditated than heresy. Nevertheless confiscation did happen because magistrates anticipated forfeiture by seizing possessions upon arrest or flight. As soon as Edmund Allin and his wife were arrested, the justice of the peace by whom they were committed, Sir John Baker, 'immediately sent vnto their house, certaine of his men ... to take an inuentorie of all the goodes' there. ${ }^{85}$ While 


\section{P. R. CAVILL}

Roger Holland was away from London concealing his child, Bishop Bonner 'caused his goodes to be seased vppon'. ${ }^{86}$ The brewer Derek Carver was caught red-handed in the act of hosting a Protestant gathering in his house at Brighton in 1554. An extensive seizure resulted, for Carver was 'a man, whome the Lorde had blessed as well with temporall riches, as with hys spirituall treasures ... of the which, there was such hauocke made, by the greedye raueners of that time, that hys poore wyfe and children had little or none thereof'. The crown raised $£ 40$ os $10 d$ from the contents of Carver's household and from debts due from purchasers of his barrels of beer; but $£ 24$ in ready money had previously been bestowed on a friend to keep safe for Carver's children. ${ }^{87}$

Pre-emptive confiscation was common for serious crimes. ${ }^{88}$ In 1553 royal servants inventoried the property 'of all suche persones as wer then attaincted, or that before the ende of the Parliament then nexte ensueng shulde be attaincted ${ }^{89}$ Forfeiture was anticipated partly because of legal opinion that, in the interval between offence and conviction, goods and chattels (but not land) might legitimately be given away or sold. ${ }^{90}$ John Philpot, Edwardian archdeacon of Winchester, objected to his dispossession on the basis that 'the statutes of this Realme ... geueth this benefit to euery person, thogh he be an heretike, to enioy his liuyng vntill he bee put to death for the same'. ${ }^{91}$ Such premature deprivation did not render the act of 1414 irrelevant; rather, it shows how seizure as a discretionary magisterial action and forfeiture as a legal fact could be distinguished in time and by agency. The experience of a leading Edwardian clergyman, whose property provided cure of souls, was not necessarily typical; similarly, Justice Baker was a vigorous opponent and the Allins recidivists. ${ }^{92}$ Other martyrs were left free to give away personal property, as the law allowed. Distinguishing between actual dispossession and potential forfeiture helps to account for the complex picture that emerges of martyrs' behaviour in prison. 


\section{HERESY AND FORFEITURE}

Although it deprived individuals of the freedom to pursue their livelihoods, imprisonment did not result in absolute dispossession. Prisoners held on to personal effects, including religious texts, up until the moment of death, as the statute of 1414 had envisaged. On 20 March 1557 one of Norwich's sheriffs delivered to the mayor's court 'Fowre [five?] bookes that were one William Carman an heretyke lately brent a byble atestamente \& iij salters'. ${ }^{93}$ Prisoners usually needed money in order to pay for meals; John Philpot settled his debts to his gaolers at the stake. ${ }^{94}$ Some were still able to dispatch funds to support those outside: from Newgate gaol in June 1555, Robert Smith sent to his wife Anne a purse and money given by six other prisoners (four of whom were burnt that same week), and to others 'tokens', objects whose worth lay in recalling him to mind rather than in their face value. ${ }^{95}$ The strictness of prison regimes varied between 'close' detention and 'at liberty'. ${ }^{96}$ The warden of the Fleet prison in London even allowed one detainee to retain minstrels, although the privy council put a stop to that. ${ }^{97}$ Lax regimes partly reflected the fact that, in the case of religious prisoners, conviction was not the objective of the authorities, but resulted from a failure of persuasion. ${ }^{98}$ Consequently, the crown allowed some to settle their debts, which reduced the value of a potential forfeiture because upon conviction offenders' debts would be annulled anyway. ${ }^{99}$ Obtaining temporary discharge from the bishop of Norwich's custody, perhaps 'of a purpose' (that is, as a ruse), Simon Miller returned to King's Lynn, 'where hee continued a certayne space, while he had disposed and set there all things in order', before returning to reaffirm his faith and burn in July $1557 .{ }^{100}$

Many Protestants suffered long periods of incarceration: three Sussex men held for heresy in November 1556 remained in the sheriff's custody one year later. ${ }^{101}$ Like other prisoners, those detained on grounds of religion were expected to pay for their keep. ${ }^{102}$ In 1556 the wardens of London's gaols were forbidden from allowing 'any of thier prisoners to begg for thier fees any more abrode in the stretes'. ${ }^{103}$ Religious division sometimes 


\section{P. R. CAVILL}

transformed the charitable relief of prisoners into a partisan expression of confessional allegiance. ${ }^{104}$ Rowland Taylor, minister of Hadleigh in Suffolk, was so generously 'susteined all the time of his imprisonment by the charitable almes of good people that visited him' that he distributed the surplus to the poor on his way to execution in $1555 .{ }^{105}$ Sympathizers also gave prisoners necessities and supported their families; those brave enough to visit gaols risked arrest themselves. ${ }^{106}$ Fearful of a precedent from Henry VIII's reign, an anonymous gentleman did not dare give the penniless Cranmer money for his dinner following his degradation, but attempted to pay his gaolers, the bailiffs of Oxford, to do so instead. ${ }^{107}$ For once, such concern was unfounded. ${ }^{108}$ Every act of charity need not have implied a shared religious position, however. An account of Cranmer's execution reveals the emotional complexity of responses to Marian penal policy. This eyewitness noted several reactions, each more in sorrow than in anger; but for his own part, the author, while sympathizing viscerally with Cranmer's suffering, blamed the archbishop for his fate. ${ }^{109}$

Sustaining Protestants during their imprisonment was one expression of support; standing surety for the accused was another, and helping them to evade forfeiture a third. ${ }^{110}$ Cuthbert Simpson, deacon of London's underground congregation, acted as executor to the capital's prisoners. ${ }^{111}$ Marion Seaman received the assistance of the Protestant William Duncan in settling fifty-six acres of land in Mendlesham twelve days after her husband William's execution in May 1558. ${ }^{112}$ Famously, the neighbours of John Noyes of Laxfield in Suffolk extinguished their hearth-fires in an attempt to thwart his execution in September 1556. ${ }^{113}$ Five had already taken custody of Noyes's lands on 27 March, three weeks prior to his arrest; this conveyance prevented the forfeiture that would have resulted from his conviction on 16 May, and thus provided for Noyes's family. ${ }^{114}$ Such support for a victim's family need not necessarily have entailed assent to the martyr's religion, however. After all, 


\section{HERESY AND FORFEITURE}

mid sixteenth-century legislators alleviated the impact of forfeiture on the widows and heirs of traitors and felons; but that did not mean that they countenanced their capital offences. ${ }^{115}$

Custom at an execution also constrained forfeiture. Protestants usually bestowed personal property on their way to the stake without hindrance, despite the fact that upon conviction their goods were forfeit to the crown. Elizabeth Folkes may have been prevented from giving her petticoat to her mother because of her mother's demonstrative approval of her stand. ${ }^{116}$ John Bradford requested permission from an unsympathetic sheriff before giving his garment to his servant. ${ }^{117}$ Nicholas Ridley’s clothing went to his brother-in-law, who had maintained him in prison, and to the bailiffs; lookers-on - some sympathizers, some gentlemen in the retinue of the presiding magistrates, and some simply bystanders - received coins, napkins, spices, and even a sundial. Ridley's divesting, Foxe implied, degenerated into an undignified free-for-all. ${ }^{118}$ By contrast, Rowland Taylor didactically measured out gifts to his parishioners; pointedly, he gave his boots to the disreputable servant of a conservative adversary, who had supposedly coveted them. ${ }^{119}$

In these final bequests, Protestants both conformed to and subverted the charity expected of those about to be executed. The authorities sometimes gave the condemned money to distribute as alms: the duke of Northumberland was thus favoured in August 1553. ${ }^{120}$ The bailiffs of Ipswich, having confiscated a coiner's possessions, gave him $20 \mathrm{~d}$ to distribute at his execution in 1557 or $1558 .{ }^{121}$ At Chester, however, the Protestant George Marsh refused spectators' gifts of purses with which to purchase masses for his soul, but wished that the money be given to prisoners or paupers instead. ${ }^{122}$ When poor men sought alms, James Abbes, having no money, stripped off in order to give his clothes; although Foxe emphasized his spontaneity, Abbes would have anticipated this request. ${ }^{123}$ Such displays were designed to demonstrate how the martyrs were holy and devout Christians. Heretics manifested only the 'pretensed charity' of hypocrites Catholics retorted: as St Paul had 


\section{P. R. CAVILL}

taught, the outer actions of giving away everything to the poor and of being burnt were worthless without an inner affection towards God. ${ }^{124}$

The stake provided the final, poignant occasion to present petitions for the material well-being of one's family. Nicholas Ridley's requests were attentively recorded because Foxe's source, Ridley's brother-in-law George Shipside, had been their principal object. ${ }^{125}$ John Noyes asked the under-sheriff George Waller 'to be good to his wyfe and children' and also to deliver to them his psalter, which (Foxe noted) he did not do. On 20 May 1556, four days after Noyes's conviction, Waller had seized goods worth $36 s$, for which sum the sheriff and the escheator later accounted; but the psalter did not appear on the list. ${ }^{126}$ Perhaps the under-sheriff kept the book himself, gave it to another, sold it on, or destroyed it as a suspect text. Here may be a glimpse of the local corruption that never was recorded, but which undoubtedly accounted for a significant, but unascertainable, proportion of the property technically forfeited. For a rounded understanding, we must therefore consider not only the neighbours, trustees, and prison visitors who lessened the impact of forfeiture, but also the magistrates, local officers, and inquest jurors who implemented the penalty, and the manorial lords and grantees who, alongside the crown, sometimes benefited from it.

III

A case-study of the county of Essex reveals the range of people whom forfeiture involved and illuminates how they responded. Conventional discussion of Marian religious policy in the county depends upon the binary model of support versus obstruction. ${ }^{127}$ Here the contours of the traditional narrative are pronounced: cruel persecutors oppressed a large body of the faithful in the teeth of popular sympathy. Thus the weight of responsibility falls on Foxe's vividly characterized persecutors, including the turncoat Richard, Lord Rich, the sadistic Edmund Tyrrell, and the fierce Anthony Browne. Reading Foxe against the grain, revisionist 


\section{HERESY AND FORFEITURE}

analyses see instead diligent justices and conscientious churchmen working together to detect and prosecute heresy. ${ }^{128}$ There remains, however, a sense in which only a zealous minority engaged with Marian policy. A little, much-cited contemporary testimony does suggest that Essex's bailiffs, constables, and jurors discharged their duty to detect heresy selectively or subverted it entirely. ${ }^{129}$ Yet because Foxe preferred to attribute responsibility for persecution to a small number of named individuals, his narrative may well have underplayed the role of others, less prominent than these villains. ${ }^{130}$ An examination of forfeiture in Essex establishes widespread 'collaboration' with Marian policy. This evidence, however, cannot be resolved into either support or obstruction. Instead, it strengthens the case for interpreting such interactions in terms of law-mindedness.

The potential for forfeiture in Marian Essex was considerable, for the county produced more martyrs than any other and generated a large, if unknown, number of exiles and fugitives. The justices of the peace (including Rich, Tyrrell, and Browne) led the way in the detection of heretics. Formal responsibility for administering forfeiture, however, was divided principally between the sheriff, the escheator, and the bailiffs of Colchester, who all served annual terms of office. The town received the property of criminals within its jurisdiction; in Mary's reign, it also burnt twenty-three Protestants, including fifteen inhabitants. ${ }^{131}$ Colchester claimed the goods of traitors in 1549 , of a felon hanged at Norwich in 1555 , and possibly of a religious fugitive in $1556 .{ }^{132}$ Unfortunately, the chamberlains' accounts for the Marian period have not survived. Essex's magistrates had, on occasion, a personal interest when a convicted heretic was also their tenant. Several sources used here relate to the honour of Rayleigh, which was centred on the hundred of Rochford in the south of the county. An honour was a seigniory comprising several manors with different owners but under one paramount lord, who in this case was Richard Rich until $1558 .{ }^{133}$ 


\section{P. R. CAVILL}

Essex's first martyrs suffered in March 1555. In response to a writ de heretico comburendo of 11 March, the sheriff Edward Brocket took custody on 24 March in London of six condemned heretics. There Brocket received instructions from the privy council and forwarded its letters commanding the earl of Oxford, Lord Rich, and others to attend the executions. He delivered the priest John Laurence to the bailiffs of Colchester, who would burn him on 29 March. Following instructions, Brocket travelled with the other prisoners to specified locations. (The writ required Brocket to execute Steven Knight at either Maldon or Saffron Walden and Thomas Cawston at either Rayleigh or Rochford.) Upon the council's order, he postponed the first burning until after the feast of the Annunciation on 25 March. Brocket then executed William Hunter at Brentwood and Thomas Higbed at Horndon on the Hill on 26 March, Thomas Cawston at Rayleigh on 27 March, Steven Knight at Maldon on 28 March, and William Pygot at Braintree on 29 March. ${ }^{134}$

On 2 April the crown appointed a commission to inquire into the property of these six men and also to identify inhabitants who had left the realm without licence. ${ }^{135}$ Heading this commission were the justices of the peace and the bailiffs of Colchester. The 'substanciall bookes and Inventories' that they were supposed to return to chancery, if they ever existed, have not been preserved. All that survives of the commissioners' activities are the inquisitions on Thomas Cawston (described as a gentleman of Rayleigh or Thundersleigh) and Thomas Higbed (described as a yeoman from Horndon). ${ }^{136}$ These inquisitions were held at Maldon on 9 April before Edmund Tyrrell, his distant cousin Sir Henry Tyrrell, Anthony Browne, and three other justices of the peace. ${ }^{137}$ It may not be a coincidence that Cawston and Higbed were probably the most prosperous of the six men. Bishop Bonner had made especial efforts to obtain their conversion; he had condemned them on 9 March, a month after the other four men named in the commission. ${ }^{138}$ 


\section{HERESY AND FORFEITURE}

The inquisitions' purpose was to identify and appraise the forfeited property. Valued at $£ 113 s 4 d$, Cawston’s goods and chattels probably constituted the contents of his household, for they included four bedsteads. Higbed's goods and chattels comprised the contents of Horndon House, which he had leased; they were worth the greater sum of $£ 2811 \mathrm{~s}$ $5 d$. Higbed possibly had not disposed before his arrest of as many valuable and portable possessions as had Cawston. At Maldon on 9 April, another member of the Tyrrell family, the courtier George, presented a letter from the privy council granting him Higbed's lease and possessions. ${ }^{139}$ Cawston's forfeiture also affected the Tyrrells. Cawston held woodland in the manor of Beaches, of which manor Edmund held the reversion. Cawston's woods may have been the location for the clandestine Protestant meetings that Edmund broke up. Because this manor formed part of the honour of Rayleigh, the present owners, George and Alice Foster, owed Richard Rich homage when they re-entered Cawston's lands. ${ }^{140}$ Cawston also held land directly of Rich within the manor of Rayleigh. Having compensated the crown for year, day, and waste, Rich sold this land to John Cooke, the honour's steward, for $£ 20 .{ }^{141}$ Cooke then assisted the commissioners by delivering Higbed's inquisition to chancery. ${ }^{142}$

These inquisitions suggest how effective a special commission could be at identifying forfeitures. The county bench lent its authority to the process. The Tyrrells' involvement was particularly intense: Edmund had been Cawston's neighbour, Henry signed the inquisitions, and George knew beforehand what Higbed had forfeited. The commissioners did not rely solely upon the jury to identify Cawston and Higbed's property, and might have employed, under the terms of the commission, 'all other polyticke wayes and meanes'. Moreover, the inquisitions were held only a fortnight after the executions. Perhaps Essex's magistrates had requested this commission, for one devised at Westminster could have taken longer to be issued. Yet no further special commissions into the estates of convicted heretics in the county are known to have been issued. The commissions issued in 1556 concerned only fugitives. ${ }^{143}$ 


\section{P. R. CAVILL}

In terms of royal policy, forfeiture may have mattered more as a means of coercing the living than of punishing the dead. Profit was thus a secondary concern.

The routine administration of forfeiture continued, however. On 3 July 1557 the exchequer instructed the county's escheator, Nicholas Bristow, to inquire into the property of twenty-one outlaws and of eighteen Protestants (including the same six men), who had been convicted between 9 February 1555 and 13 April $1556 .{ }^{144}$ The list seems to have been compiled from Bishop Bonner's writs relinquishing heretics to the secular arm to be burnt. ${ }^{145}$ A single inquisition was then held at Chelmsford on 2 September $1557 .{ }^{146}$ In each case, the jury found that the individual had possessed no property on the day of his or her conviction. The contrast between these findings and the earlier inquisitions on Cawston and Higbed needs explaining. In April 1555 the justices of the peace had brought a greater and more personal authority to bear than might the escheator when administering a routine inquisition. That fact could imply that this later jury chose not to cooperate; yet the same jury delivered identical verdicts for the twenty-one outlaws. In ordinary felony trials, it was standard practice for jurors to return $n u l$. cat. (no chattels), a convention which may have conditioned this jury’s response. ${ }^{147}$ Ignorance of individual circumstances may have played a part too. The fugitives commissions of 1556 empanelled juries for each hundred, whereas the Chelmsford jury responded for the whole county. Asking in a single inquisition about thirtynine people, mostly unrelated, perhaps discouraged scrutiny of any individual. The principal defect, however, was probably the time that had elapsed since the convictions, for in the meanwhile property could have been concealed or misappropriated.

Another possible explanation for the nil return was that the commission of 2 April 1555 had alerted Protestants to the need to protect against forfeiture. The Chelmsford jury reported that Cawston, Higbed, and also Thomas Watts possessed no property apart from that already presented before this commission. Watts's inclusion is curious because he did not 


\section{HERESY AND FORFEITURE}

appear in the commission, as he was arrested only on 26 April and convicted on 18 May 1555. No inquisition has survived; it might not have found much, for Watts, 'before he was apprehended, had sold and made away his cloth in his shop, and disposed his things being set in order to his wyfe and children, \& gaue away much of his cloth vnto the poore'. ${ }^{148}$ Watts also surrendered his lands in Billericay in order that they be re-granted to his son William, seven daughters, and sister. (Watts probably did not make any provision for his wife Elizabeth because by convention she would receive one third of his customary lands anyway.) Following Watts's execution in June, the manor court admitted his relatives and appointed his closest friend John Harris as William's guardian. The lord of the manor was Richard Rich, and in December Harris gave Rich $£ 30$ as an entry fine and for confirmation of his title. ${ }^{149}$ Perhaps William paid the price for his father's public rebuke of Rich at the stake, for having betrayed his role as patron of the county's evangelicals under Edward VI. ${ }^{150}$

The success of the inquisitions into Cawston and Higbed was thus unlikely to have been widely replicated. The Munt family of Great Bentley were among the twenty-two suspects sent to London in August 1556, but then allowed to return home upon a vague submission. At the manor court on 15 January 1557, William surrendered his land in order that it be re-granted with a remainder to the son of his first marriage, John. The persistent refusal of William, his second wife Alice, and his step-daughter Rose to attend church and their criticism of neighbours' devotion led to their re-arrest in March, conviction in June, and execution in August. On 14 January 1558 the manor court recorded William and Alice's deaths, admitted John (then aged 15) to the lands, and accepted his uncles as guardians. Such evidence might be taken to indicate neighbours' sympathy for the family; yet jurors at the two manor courts had signed a letter denouncing the Munts. ${ }^{151}$ What reconciled these two positions may have been a law-mindedness that defended authorized religion and also upheld property rights. The principal limitation of forfeiture could have been the self-imposed 


\section{P. R. CAVILL}

restriction of that mindset, rather than opposition to the punishment of religious dissent per se.

The case of William Coker, a yeoman of Hazeleigh, showed how the government too respected the legal bounds of forfeiture. Coker was apparently Essex's most profitable martyr. He was convicted of heresy at Canterbury on 2 August and burnt there on 23 August 1555. Essex's escheator that year, John Swallow, on his own initiative held two inquisitions, at Chelmsford on 3 October and at Stratford Langthorne on 30 October. ${ }^{152}$ The extent and complexity of Coker's estate possibly required two inquisitions. The two juries itemized and valued Coker's personal property, which was worth $£ 10219 s 10 \mathrm{~d}$. The Chelmsford inquisition identified 270 livestock at the manor of Bremstons in Purleigh (worth $£ 715 s 4 d$ ). The Stratford inquisition identified a debt of $£ 25$ owed to Coker by the man to whom he had leased this manor to farm, for debts owing to an offender became payable to the crown. ${ }^{153}$ The remaining sum ( $£ 614 s 6 d$ ) consisted of the value of Coker's 'householde stuff' at the manor house in Hazeleigh, which the Stratford jurors listed room by room. In the great parlour hung a tablet of the king's arms (probably of Edward VI), and in another room a tablet depicting the story of Adam and Eve.

The two inquisitions also identified Coker's extensive land holdings around Hazeleigh and around Halstead. They revealed how Coker had conveyed away land between 12 February and 3 July 1555. The most important transaction occurred on 20 February, when Coker had conveyed much of his estate to two Londoners, the cutler Christopher Curley and the pewterer John Hicks. On 28 February Curley and Hicks had agreed to stand seised to the use of Coker for term of his life and afterwards to the use of family members. Under this arrangement, Coker had parcelled out the descent of his lands between different relatives (including his sister, niece, and nephew) and others. This multi-way partition may explain why Coker had not asked members of his family to act as feoffees instead. The two 


\section{HERESY AND FORFEITURE}

Londoners probably acted out of sympathy for a fellow Protestant, for Curley must also be the man who accommodated the radical 'freewillers' Henry Hart and John Kempe in the capital. $^{154}$

Coker's actions protected some, but not all, of his estate from forfeiture. Having leased the manor of Hazeleigh for forty years in 1532, his father John had then divided the land between William and his brother Edward with the survivorship to one brother in the event of the other's death. On this basis, Edward entered his brother's portion two days after William's execution. But a lease counted as chattel real, and was thus forfeit to the crown, which granted out the remaining seventeen years on 28 November $1555 .{ }^{155}$ The lands omitted from the February conveyance also escheated to their several lords, who resumed possession and should have paid the crown for year, day, and waste. ${ }^{156}$ The arrangement with Curley and Hicks, however, succeeded because after 28 February Coker had only a life interest in these lands. Thus upon his death Coker's sister Mary Garrington obtained possession of the manor of Bremstons. ${ }^{157}$ For the crown to unravel such an arrangement would have required new legislation to extend forfeiture for heresy to forms of estate other than fee simple and leasehold. Even if such a step was considered, the defeat of the exiles bill by parliament that December possibly would have deterred the government. ${ }^{158}$

The ramifications of William Coker's conviction did not end in Mary's reign, as the descent of three parcels of land within the honour of Rayleigh reveals. Hyllyardes (a cottage), Westhylles (two closes of forty acres), and Tryndelles (six acres of land) were mistakenly held to form part of the demesne of Coker's manor of Bremstons. Omitted from the use that Coker had created in February, these lands were consequently believed to have escheated to the superior lord, Richard Rich. Hence Rich re-entered the lands, paying the crown $£ 6$ for

year, day, and waste. ${ }^{159}$ Before being held by William, the manor had passed through the hands of his father John, his oldest brother Henry (who died without issue), and his older 


\section{P. R. CAVILL}

brother Robert (who died in 1553). John had, however, granted these three parcels directly to Robert and his heirs. Although Robert had bequeathed the manor to his younger brother William, these parcels should have passed instead to Robert's daughter Mary. Yet Mary, aged three or four when her uncle was burnt, could not then enforce her title. She and her husband eventually recovered these lands through two actions of ejectment between 1579 and $1583 .{ }^{160}$ This long-postponed suit reveals the protracted impact of forfeiture: efforts to obtain restitution continued well into Elizabeth I's reign.

\section{IV}

The accession of Elizabeth I generated an expectation that the supposed wrongs of her halfsister's reign would be righted. In exile, the former bishop John Ponet had presented lawless disregard for property rights - presumably thinking of his own and those of other refugees as one manifestation of the Marian regime's tyranny. ${ }^{161}$ The descendants of those burnt had a powerful moral case: writing on behalf of Thomas Cawston's three grandsons in 1578, Bishop Aylmer urged William Cecil to 'maynetayne the poore asshis of so glorious a Martyr' ${ }^{162}$ One grandson, Nathaniel Traheron, sought to recover the land in Rayleigh that Richard Rich had re-granted to John Cooke. ${ }^{163}$ Yet the steps taken by the government fell short of the wholesale restoration that victims and their descendants might have hoped for. The heresy convictions themselves were not reversed; only in one exceptional instance (on the island of Guernsey) are they known to have been reviewed. ${ }^{164}$ This section examines what remedies were made available instead, analyses specific cases, and through them seeks to explain the limits of restitution. Again, it will be argued that the rule of law, as much as religious sympathy, determined how such suits were treated.

Parliament was the natural venue for those seeking to undo the penalties imposed in the previous reign. In 1559 Elizabeth's first parliament reversed some attainders for treason; 


\section{HERESY AND FORFEITURE}

others would be undone in later sessions. ${ }^{165}$ The restoration of clergymen deprived on grounds of religion or marriage was also raised, although the matter was remedied through the royal prerogative instead. ${ }^{166}$ Specific bills were presented that sought to recover lands lost when Mary had restored the bishops deprived under Edward VI. Only two bills became law, indicating a cautious approach to reversing the consequences of Mary's reign where property rights were concerned. Thus a bill to confirm all the grants made by the bishops deprived under Mary also failed. ${ }^{167}$ Among the unsuccessful petitioners was George Shipside, who hoped to recover the lease of a park and watermill made by his brother-in-law Nicholas Ridley when bishop of London between 1550 and 1553. Having failed in parliament, Shipside's case against the lessees of Bishop Bonner, who had replaced Ridley in 1553, was then heard in the court of requests, the star chamber, the Queen's Bench, and chancery. In 1563 chancery ruled in Shipside's favour on the grounds that Bonner's deprivation in 1550 had been lawful and hence that Ridley had legitimately succeeded him as bishop. ${ }^{168}$

During the same parliament an attempt was made collectively to help the victims of religious persecution and their descendants recover property. On 23 February 1559 a special commission for the counties of Surrey and Sussex was appointed. The terms of the commission reveal in what cases the crown would assist. ${ }^{169}$ Property seized without authority during the searching of homes or following flight was covered. This provision could have aided those who had fled within the realm, but less readily the exiles, who had broken the statute of 1382. The commission also addressed those entrusted with property who refused to honour such arrangements. The case then being brought by the Marian exile Katherine Bertie, dowager duchess of Suffolk, against her attorney exemplified this problem. ${ }^{170}$ The commission's terms implied that the crown would uphold such trusts, which was a concession: chancery normally declined to enforce arrangements created to evade a royal title. ${ }^{171}$ Yet the regime did not offer to reverse the lawful consequences of conviction. In fact, 


\section{P. R. CAVILL}

the commission was charged with seeking forfeitures due from those convicted of heresy under Mary: change of religion or not, the crown was entitled to its prerogative.

No trace of the Surrey-Sussex commission has been found in governmental records, but only in the private papers of the commissioners. Special commissions for other counties may thus have been created, yet have left no documentary trace. We know that a commission covering Essex existed and that it was headed by the earl of Oxford because a suit was removed to chancery on account of the uncooperativeness of the defendant, Sir Henry Tyrrell. ${ }^{172}$ The plaintiff, John Jeffrey, explained how he had leased a farm in Little Burstead from Tyrrell. Jeffrey claimed that, although he had fled only into Suffolk, Tyrrell falsely alleged that he had gone overseas and consequently had forfeited his goods and chattels (including this lease). Jeffrey had, in fact, left the realm, but later returned; presumably, he denied ever having gone abroad in order to avoid admitting to a breach of the statute of 1382. ${ }^{173}$ Jeffrey had, however, taken the precaution of selling the lease to his tenant, John Eyon, and made no attempt to disguise the fact that this transaction had been a sham. Yet, abusing his power as a justice of the peace, Tyrrell had supposedly intimidated Eyon into surrendering the lease to him. Upon hearing Eyon's evidence about the fiduciary nature of Jeffrey's transaction, chancery found in Jeffrey's favour in February 1561 and ordered Tyrrell to restore him to possession.

Commissions created in 1559 could not help those who were not yet of sufficient maturity to act, so cases continued to arise over the course of Elizabeth's reign. Only when Derek Carver's son came of age could he complain that the money his father had set aside was denied him. ${ }^{174}$ Another case from Sussex concerned Nicholas White of Beckley, who had been burnt in 1557, and his son Nicholas. In 1565 Thomas Kyte, guardian of the younger Nicholas, brought a case in chancery against Goddard White, who was the martyr's first cousin. According to Thomas's bill, the elder Nicholas, fearing 'losse of lyef for Relygyon in 


\section{HERESY AND FORFEITURE}

the tyme of the late [queen] of noble memorye Marye as in dede it after fortuned did for the salvacion of [his] enherytaunce' grant his lands to Goddard and John Kyte (possibly Thomas's late father). Although Goddard and John were then supposed to re-convey the lands to the elder Nicholas for term of his life with a remainder to his son, this conveyance 'was not executed By reason of thapprehensyon and great troble and losse of lyef for Religion' of the father. Consequently, Goddard had held on to the lands. Now, chancery ruled, he must surrender them to the younger Nicholas. ${ }^{175}$

Those in authority no doubt sympathized with the plaintiffs in such cases. After all, the presiding judge in chancery, the lord keeper Sir Nicholas Bacon, had helped to alleviate the consequences of his father-in-law's exile. ${ }^{176}$ But the courts never enunciated a general rule under which the former property of martyrs and other victims might be reclaimed from those now in possession with a legitimate title. The Acts and monuments recorded a single case of restitution, brought in chancery in 1563. The property of Edmund Allin and his wife Katherine of Frittenden in Kent that had been given to the parson of nearby Staplehurst 'after in the raigne of this Queene ... was by right law recouered from him againe'. Foxe did not explain that this was because the property had belonged to William Morleyn, Katherine's son by her first marriage, and not to the Allins. ${ }^{177}$ In legal terms, the Allins' martyrdom was irrelevant to the case: the verdict would have been the same had they been common felons.

In 1565 the chief justice of the common pleas, Sir James Dyer, did deliver an opinion of wide potential application in a case concerning an unnamed Protestant burnt in Mary's reign. Dyer reasoned that because copyhold tenure was neither land nor tenement, it was not covered by the statute of 1414 , and hence could not have been forfeit. ${ }^{178}$ Again, however, the principle - strict interpretation of penal statutes - was unconnected to the nature of the offence. ${ }^{179}$ The following year, Thomas Spurdance presented to the court of requests a 


\section{P. R. CAVILL}

petition concerning his father, also called Thomas, who had been burnt in 1556 . The elder Thomas had been convicted of

certayne causes of heresye as they thene termed them that is to saye for that he dyd denye the Masse to be A Sacrafyse propiciatorye, and that mane was not saved by his workes without faythe, and that Pylgerimages Purgatorye \& offeringe to Sayntes was but the inventioun of mane and browght into the churche for the maynteyninge of the pryde \& coveteousnes of the clergye.

The resulting escheat of his father's lands in Crowfield (Suffolk) to the lord of the manor, the younger Thomas complained, was against 'your graces proceadinges in causes of trewe religioun'. Nevertheless, although the court ruled in Thomas's favour, it was on the grounds that these lands were copyhold, not on the grounds of his father's now-orthodox beliefs. ${ }^{180}$ The Elizabethan courts probably heard many other cases that addressed the consequences of forfeiture in the previous reign. The evidence presented here seems sufficient, however, to establish that restitution relied upon individual suits rather than collective reparation, and upon points of law rather than claims of martyrdom. On both counts, much property may never have been recovered.

From a study of forfeiture, the burnings emerge as a single dimension of the penal response to religious dissent in Marian England. Reliance on Foxe's framework distorts our sense of the regime's policies and of Protestantism, however critically we read the Acts and monuments. Examining a punishment other than burning through a contrasting and complementary set of sources has therefore advanced our understanding in several ways. By 


\section{HERESY AND FORFEITURE}

concentrating on the martyrs, Foxe focused on the regime's failures. Evidence of evasion reveals the martyrs as rational and purposeful, rather than deluded and fanatical. If forfeiture failed in their cases, then so too did burning. The loopholes worth closing concerned the living, not the dead. In these cases, dispossession may have been an effective punishment, especially if we remember internal refugees. Understandably, given their significance in Elizabeth's reign, continental exiles have almost monopolized scholarly attention. ${ }^{181}$ Yet Protestants who survived Marian England not only dissembled: they also suffered. Dividing Protestants into exiles, martyrs, and conformers may fail to do them justice; the term Nicodemite should probably be reserved for discussion of contemporary polemical writing. Thus an exploration of forfeiture underlines the breadth of Protestant experience in Marian England. While the two subjects will always be closely linked, studies of Marian Protestantism ought to be extricated from John Foxe.

Examining forfeiture also casts light on the popularity of the regime's policies. So many interactions have been identified between magistrates, officers, jurors, lords, grantees, neighbours, trustees, prison visitors, and guardians that no single answer satisfies. While help in mitigating the effects of forfeiture could suggest that Protestant sentiment was widespread, it proves difficult to disentangle sympathy for the religion from sympathy for particular people - but perhaps the two were, in reality, inseparable. Because individual motivation is mostly irrecoverable, it seems preferable to conceive of popular engagement or 'collaboration', referring to external action rather than internal belief. ${ }^{182}$ Rational self-interest turns out, however, to be an unsatisfactory model because, even in the case of forfeiture, profit did not predict the conduct of the crown or anyone else. Instead, early modern Englishmen and women obeyed, observed, and enforced laws, and expected others to do so, on principle. Thus they upheld the property rights of others, whether or not they approved of their religion, because these rights were their own as well. ${ }^{183}$ Remarkably, this statement 


\section{P. R. CAVILL}

holds true for the crown, which respected rules that a literally 'absolute' monarchy might not have regarded. Although the legal basis for royal action against exiles and fugitives was contested, greater consensus covered the law of forfeiture than the grounds on which it was imposed. The example of forfeiture therefore supports the conclusion that might be drawn from the success of contemporaneous defences of property rights: Queen Mary's accession itself, the failure to restore former church lands, and (ironically) the rejection of the exiles bill. What made forfeiture enforceable and acceptable, if not popular in its usual sense, was belief in the rule of law - and that did not change in 1558.

In Elizabeth's reign, property seized under Mary was not automatically restored, a point that Foxe's perspective renders incomprehensible: the legal system that had constrained forfeiture now restricted restitution. The Elizabethan regime also punished Catholic fugitives and recusants with dispossession. It secured the passage of an exiles bill similar to that which had failed in 1555, and closed some loopholes that Marian Protestants had exploited to protect their property. ${ }^{184}$ Yet trusts continued to enable Catholics to escape punishment for their beliefs. ${ }^{185}$ As penalties for religious dissent, fines, distraint, and sequestration became more noticeable, spawning in the seventeenth century their own martyrologies. ${ }^{186}$ Martyrologies inform but they also mislead, not only in obvious ways. Foxe's account of the burnings isolates Mary's reign; forfeiture re-integrates it within the history of tolerance and intolerance in early modern England. Recent work on this subject after 1558 undermines the idea that confessional difference dominated everyday life. ${ }^{187}$ Instead, the circumstantial interplay of personal, official, and social impulses determined the selective and sporadic application of penal policy. Since tolerance and intolerance sprang from the same religious motive, the two impulses were in dialogue rather than in opposition. Another factor could also account for that complex equilibrium: belief in the rule of law. Law-mindedness may 


\section{HERESY AND FORFEITURE}

have helped to mediate between the demands of the confessional state and the problem of this increasingly religiously pluralistic society. 


\section{P. R. CAVILL}

Pembroke College, Cambridge, CB2 1RF pc504@cam.ac.uk

* I am very grateful to Tom Freeman, Neil Jones, Krista Kesselring, and Christopher Whittick for commenting on this article. I also thank seminar audiences in London and Oxford for their suggestions. I acknowledge the support of the Arts and Humanities Research Council through the award of a research fellowship.

${ }^{1}$ References are to the 1563 or 1583 edition: John Foxe, Actes and monuments (London, 1563); idem, Actes and monuments (2 vols., London, 1583). The two volumes of the 1583 edition share one pagination; all references are found in the second volume.

${ }^{2}$ See, for example, Patrick Collinson, 'Truth and legend: the veracity of John Foxe's Book of Martyrs', in his Elizabethan essays (London and Rio Grande, OH, 1994), pp. 151-77; idem, 'The persecution in Kent', in Eamon Duffy and David Loades, eds., The church of Mary Tudor (Aldershot, 2005), pp. 309-33; Elizabeth Evenden and Thomas S. Freeman, Religion and the book in early modern England: the making of Foxe's 'Book of Martyrs' (Cambridge, 2011).

${ }^{3}$ David Loades, The religious culture of Marian England (London, 2010), pp. 132-3.

${ }^{4}$ Eamon Duffy, Fires of faith: Catholic England under Mary Tudor (New Haven, CT, and London, 2009), chs. 4-8; Thomas S. Freeman, 'Burning zeal: Mary Tudor and the Marian persecution', in Susan Doran and Thomas S. Freeman, eds., Mary Tudor: old and new perspectives (Basingstoke, 2011), pp. 171-205, 313-20.

${ }^{5}$ Foxe, Actes and monuments (1583), pp. 1484ff, 2058ff, 2062ff, $2099 \mathrm{ff}$.

${ }^{6}$ See, for example, Robert Whiting, The reformation of the English parish church (Cambridge, 2010), pp. 20, 35, 52, 70, 84, 116, 134, 148, 166, 181, 198, 228, 236-7. 


\section{HERESY AND FORFEITURE}

${ }^{7}$ Andy Wood, The 1549 rebellions and the making of early modern England (Cambridge, 2007); David Rollison, A commonwealth of the people: popular politics and England's long social revolution, 1066-1649 (Cambridge, 2010).

${ }^{8}$ Ethan H. Shagan, Popular politics and the English Reformation (Cambridge, 2003), pp. $12-$ 25.

${ }^{9}$ K. J. Kesselring, 'Felony forfeiture and the profits of crime in early modern England', Historical Journal, 53 (2010), pp. 271-88.

${ }^{10}$ Joel B. Samaha, 'Hanging for felony: the rule of law in Elizabethan Colchester', Historical Journal, 21 (1978), pp. 763-82; M. L. Bush, 'The Tudor polity and the Pilgrimage of Grace', Historical Research, 80 (2007), pp. 47-72; E. W. Ives, 'The reputation of the common lawyer in English society, 1450-1550', University of Birmingham Historical Journal, 7 (1960), pp. 130-61.

${ }^{11}$ Christopher W. Brooks, Law, politics and society in early modern England (Cambridge, 2008); Alan Cromartie, The constitutionalist revolution: an essay on the history of England, 1450-1642 (Cambridge, 2006).

${ }^{12}$ Robert Tittler and Susan L. Battley, 'The local community and the crown in 1553: the accession of Mary Tudor revisited', Bulletin of the Institute of Historical Research, 57 (1984), pp. 131-9; Anna Whitelock and Diarmaid MacCulloch, 'Princess Mary’s household and the succession crisis, July 1553', Historical Journal, 50 (2007), pp. 265-87; E. W. Ives, 'Tudor dynastic problems revisited', Historical Research, 81 (2008), pp. 255-79, at pp. 26772.

${ }^{13}$ John Edwards, Mary I: England's Catholic queen (New Haven, CT, and London, 2011), pp. 138, 214-20, 237-8, 306-7; Jennifer Loach, Parliament and the crown in the reign of Mary Tudor (Oxford, 1986), pp. 76, 86-7, 108-15. 


\section{P. R. CAVILL}

${ }^{14}$ K. J. Kesselring, 'Felony forfeiture in England, c.1170-1870', Journal of Legal History, 30 (2009), pp. 201-26.

${ }^{15}$ Andrew Pettegree, Marian Protestantism: six studies (Aldershot, 1996), pp. 3-4.

${ }^{16}$ David Loades, 'John Foxe and the traitors: the politics of the Marian persecution', in Diana Wood, ed., Martyrs and martyrologies (Studies in Church History, vol. 30, Oxford, 1993), pp. $231-44$.

${ }^{17}$ John Christopherson, An exhortation to all menne to take hede and beware of rebellion (London, 1554), sigs. N8r-O3r, Y1r, Aa8r, Bb4r-Cc3v; Miles Hogarde, The displaying of the Protestantes (London, 1556), sigs. M5v-M7v.

${ }^{18}$ D. M. Loades, Two Tudor conspiracies (Cambridge, 1965), pp. 96 n. 2, 100, 102, 107, $116-27,235-7,253-7$.

${ }^{19}$ John Roche Dasent, ed., Acts of the privy council: new series (32 vols., London, 1890 1907), IV, pp. 310-12, 316, 323-4, 328, 333, 403-5.

${ }^{20}$ John Bellamy, The Tudor law of treason: an introduction (London, Toronto, and Buffalo, 1979), pp. 26-7, 30, 34-5, 51-2, 54-55, 59, 88, 210-11.

${ }^{21}$ The National Archives (TNA), E154/2/39, fos. 1r-48v passim; E154/2/41, fos. 6r-v, 9r10r; E154/2/45, fos. 7r-10r, 16r-17r; E154/4/38; E154/6/41/7; Dasent, ed., Acts of the privy council, IV, pp. 351-2.

${ }^{22}$ S. T. Bindoff, ed., The history of parliament: the House of Commons, 1509-1558 (3 vols., London, 1982), I, pp. 578-81, III, pp. 458-60.

${ }^{23}$ Foxe, Actes and monuments (1583), p. 1844.

${ }^{24}$ TNA, E154/2/39, 41, 45.

${ }^{25}$ Kesselring, 'Felony forfeiture and the profits of crime', pp. 274, 279.

26 David Loades, The mid-Tudor crisis, 1545-1565 (Basingstoke, 1992), pp. 60-8. 


\section{HERESY AND FORFEITURE}

${ }^{27}$ W. C. Richardson, ed., The report of the royal commission of 1552 (Morgantown, WV, 1974), pp. 11, 34-5, 102, 170, 196, 224-5.

${ }^{28}$ Foxe, Actes and monuments (1563), p. 1679; Christina Hallowell Garrett, The Marian exiles: a study in the origins of Elizabethan puritanism (Cambridge, 1938).

${ }^{29}$ Loach, Parliament and the crown, pp. 138-43.

${ }^{30} 5$ Ric. II, st. 1, c. 2; Kesselring, 'Felony forfeiture in England', pp. 204-5.

${ }^{31}$ TNA, E143/29/192; E387/1/211. This proclamation has not been identified.

${ }^{32}$ Marjorie Keniston McIntosh, A community transformed: the manor and liberty of Havering, 1500-1620 (Cambridge, 1991), pp. 193, 195.

${ }^{33}$ Sarah Covington, 'Heretic hunting beyond the seas: John Brett and his encounter with the Marian exiles', Albion, 36 (2004), pp. 407-29.

${ }^{34}$ Sir James Dyer, Les reports des divers select matters \& resolutions des reverend judges \& sages del ley (London, 1688), fo. 128v; TNA, E143/29/113.

${ }^{35}$ G. R. Elton, 'The rule of law in sixteenth-century England', in his Studies in Tudor and Stuart politics and government (4 vols., Cambridge, 1974-92), I, pp. 260-84; E. W. Ives, The common lawyers of pre-Reformation England: Thomas Kebell: a case study (Cambridge, 1983), chs. 10-11.

${ }^{36}$ TNA, E368/339, brevia retornabilia, Michaelmas; E387/1/211-22.

${ }^{37}$ Dasent, ed., Acts of the privy council, v, p. 97.

${ }^{38}$ TNA, E387/1/212A, 218; E368/338, recorda, Michaelmas, rot. 105.

${ }^{39}$ TNA, E387/1/221-2; E368/338, recorda, Hilary, rot. 19.

${ }^{40}$ D. M. Loades, 'The Essex inquisitions of 1556', Bulletin of the Institute of Historical Research, 35 (1962), pp. 87-97; P. R. Cavill, 'The Essex inquisitions of 1556: the Colchester certificate', Historical Research (forthcoming).

${ }^{41}$ Foxe, Actes and monuments (1583), p. 1971. 
${ }^{42}$ Foxe, Actes and monuments (1563), pp. 1676-9.

${ }^{43}$ Dasent, ed., Acts of the privy council, v, p. 326.

${ }^{44}$ Catharine Pullein, Rotherfield: the story of some Wealden manors (Tunbridge Wells, 1928), p. 267, citing East Sussex Record Office, ACC/2953/85, fos. 2v, 30r, 38r.

${ }^{45}$ Foxe, Actes and monuments (1583), p. 1912; Suffolk Record Office (Ipswich Branch), HD $1538 / 302 / 21$, fo. $10 r-v$.

${ }^{46}$ Foxe, Actes and monuments (1583), p. 2045.

${ }^{47}$ Pettegree, Marian Protestantism, pp. 6-7, 86-9, 98-117.

${ }^{48}$ M. A. Overell, 'Vergerio's anti-Nicodemite propaganda and England, 1547-1558', Journal of Ecclesiastical History, 51 (2000), pp. 296-318.

${ }^{49}$ See, however, Brett Usher, "In a time of persecution”: new light on the secret Protestant congregation in Marian London', in David Loades, ed., John Foxe and the English Reformation (Aldershot, 1997), pp. 233-51.

${ }^{50}$ Jonathan Wright, 'Marian exiles and the legitimacy of flight from persecution', Journal of Ecclesiastical History, 52 (2001), pp. 220-43, at pp. 236-40.

${ }^{51}$ P. R. Cavill, 'Heresy, law, and the state: forfeiture in late medieval and early modern England', English Historical Review (forthcoming).

${ }^{52}$ F. Donald Logan, Excommunication and the secular arm in medieval England: a study in legal procedure from the thirteenth to the sixteenth century (Toronto, 1968), pp. 20-1, 109. ${ }^{53}$ TNA, E379/141 (1555-6).

${ }^{54}$ TNA, C85/48/20.

${ }^{55}$ Pullein, Rotherfield, pp. 266-7, citing East Sussex Record Office, ACC/2953/85, fos. 3v, $19 v-20 r, 23 v, 26 r-v$.

${ }^{56}$ Bindoff, ed., History of parliament, III, pp. 276-8.

${ }^{57} 2$ Hen. IV, c. $15 ; 1 \& 2$ Phil. \& Mar., c. 6. 


\section{HERESY AND FORFEITURE}

${ }^{58}$ TNA, C66/907, mm. 48d-49d (Calendar of the patent rolls, 1555-1557 (London, 1938), pp. 281-2).

${ }^{59}$ Dasent, ed., Acts of the privy council, vII, p. 43.

${ }^{60}$ TNA, SP12/2, fo. $8 \mathrm{r}-\mathrm{v}$.

612 Hen. V, st. 1 , c. 7.

${ }^{62}$ TNA, E379/141 (1555-6); Thomas S. Freeman, 'Appendix: the Marian martyrs', in Doran and Freeman, eds., Mary Tudor, p. 268 n. 43.

${ }^{63}$ Kesselring, 'Felony forfeiture and the profits of crime', pp. 275-80.

${ }^{64}$ West Sussex Record Office, Add. MS 37546. I searched the honorial and hundredal court rolls at Arundel Castle unsuccessfully for resulting forfeitures.

${ }^{65}$ TNA, E357/152-5.

${ }^{66}$ Kesselring, 'Felony forfeiture in England', pp. 203-5.

${ }^{67}$ TNA, C66/917, mm. 19d-20d (Calendar of the patent rolls, 1555-1557, pp. 554-5).

${ }^{68}$ Pullein, Rotherfield, pp. 270-4, citing East Sussex Record Office, ACC/2953/85, fos. 19r, $23 \mathrm{v}, 25 \mathrm{r}, 30 \mathrm{v}$.

${ }^{69}$ Foxe, Actes and monuments (1583), p. 1836.

${ }^{70}$ Ibid., pp. 1704-5.

${ }^{71}$ Ibid., p. 1725.

${ }^{72}$ Ibid., pp. 1716-17.

${ }^{73}$ Ibid., p. 1583.

${ }^{74}$ Ibid., pp. 1538, 1677, 1936-7.

${ }^{75}$ Ibid., p. 1682.

${ }^{76}$ Ibid., p. 1683.

${ }^{77}$ Ibid., p. 1497.

${ }^{78}$ Ibid., p. 1633. 
${ }^{79}$ Neil Jones, 'Trusts in England after the Statute of Uses: a view from the 16th century', in Richard Helmholz and Reinhard Zimmermann, eds., Itinera fiduciae: trust and Treuhand in historical perspective (Berlin, 1998), pp. 185, 193; Tracey A. Sowerby, Renaissance and reform in Tudor England: the careers of Sir Richard Morison, c.1513-1556 (Oxford, 2010), pp. 225-6.

${ }^{80}$ TNA, C78/17/36.

${ }^{81}$ Brad S. Gregory, Salvation at stake: Christian martyrdom in early modern Europe (Cambridge, MA, and London, 1999), pp. 99-105.

${ }^{82}$ TNA, E357/134 (1554-5); Foxe, Actes and monuments (1583), pp. 1712, 1740; Susan Wabuda, 'Shunamites and nurses of the English Reformation: the activities of Mary Glover, niece of Hugh Latimer', in W. J. Sheils and Diana Wood, eds., Women in the church (Studies in Church History, vol. 27, Oxford, 1990), pp. 339-43; Kesselring, 'Felony forfeiture in England', pp. 206-7.

${ }^{83}$ Foxe, Actes and monuments (1583), pp. 1674, 1806, 1999.

${ }^{84}$ TNA, C142/115/47; E150/998/3; E357/113 (bound under Shropshire for 1557-8); E357/123 (1559-60); Foxe, Actes and monuments (1583), p. 2046; Kesselring, 'Felony forfeiture in England', pp. 206, 212-13 n. 59.

${ }^{85}$ Foxe, Actes and monuments (1583), p. 1979.

${ }^{86}$ Ibid., p. 2039.

${ }^{87}$ Ibid., pp. 1680, 1682; TNA, E379/141 (1554-5); C3/32/79.

${ }^{88}$ Dasent, ed., Acts of the privy council, IV, p. 394, vI, pp. 49, 66, 81; John Gough Nichols, ed., The diary of Henry Machyn (Camden Original Series, vol. 42, London, 1848), p. 51. ${ }^{89}$ TNA, E154/2/39, fo. 1r.

${ }^{90}$ Kesselring, 'Felony forfeiture in England', pp. 207-8.

${ }^{91}$ Foxe, Actes and monuments (1583), p. 1797. 


\section{HERESY AND FORFEITURE}

${ }^{92}$ Duffy, Fires of faith, p. 134; Freeman, 'Burning zeal', pp. 183-4, 189.

${ }^{93}$ Norfolk Record Office, NCR case 16a/7, pp. 138, 140.

${ }^{94}$ Foxe, Actes and monuments (1583), pp. 1537-8, 1830, 1938; John Gough Nichols, ed., Narratives of the days of the Reformation (Camden Original Series, vol. 77, Westminster, 1859), pp. 105, 128, 153.

${ }^{95}$ Foxe, Actes and monuments (1583), p. 1701.

${ }^{96}$ Dasent, ed., Acts of the privy council, VI, pp. 103, 123.

${ }^{97}$ Ibid., v, p. 135.

${ }^{98}$ Megan Wheeler, 'Protestants, prisoners and the Marian persecution' (D.Phil. thesis, Oxford, 2006), ch. 6.

${ }^{99}$ Dasent, ed., Acts of the privy council, v, pp. 140-1, 195.

${ }^{100}$ Foxe, Actes and monuments (1583), p. 2005.

${ }^{101}$ East Sussex Record Office, SAS/G36/9-10.

${ }^{102}$ Nichols, ed., Narratives of the Reformation, pp. 149, 190, 207, 209.

${ }^{103}$ Dasent, ed., Acts of the privy council, vI, p. 8.

104 Thomas S. Freeman, 'Publish and perish: the scribal culture of the Marian martyrs', in Julia Crick and Alexandra Walsham, eds., The uses of script and print, 1300-1700 (Cambridge, 2004), pp. 239-41.

${ }^{105}$ Foxe, Actes and monuments (1583), p. 1526.

${ }^{106}$ Ibid., pp. 1899, 1915, 1928, 1931; Pettegree, Marian Protestantism, pp. 101-2.

${ }^{107}$ Foxe, Actes and monuments (1583), pp. 1883-4.

${ }^{108}$ William H. Turner, ed., Selections from the records of the city of Oxford ... [1509-1583] (Oxford and London, 1880), pp. 218-19, 228-40, 317-18; Carl I. Hammer, 'A hearty meal? The prison diets of Cranmer and Latimer', Sixteenth Century Journal, 30 (1999), pp. 653-80. 
${ }^{109}$ Turner, ed., Selections from the records of Oxford, pp. 240-6; Duffy, Fires of faith, pp. $156-8$.

${ }^{110}$ Foxe, Actes and monuments (1583), p. 2070.

${ }^{111}$ Foxe, Actes and monuments (1563), p. 1652 (misprinted as p. 1632); Usher, “"In a time of persecution", pp. 244-6.

${ }^{112}$ Suffolk Record Office (Ipswich Branch), HD 1538/302/21, fo. 11r-v; Foxe, Actes and monuments (1583), pp. 1912, 2035.

${ }^{113}$ Foxe, Actes and monuments (1583), pp. 2021-2.

114 TNA, E357/93 (1556-7).

${ }^{115}$ Kesselring, 'Felony forfeiture in England', pp. 209-10, 213-14.

${ }^{116}$ Foxe, Actes and monuments (1583), p. 2008.

${ }^{117}$ Ibid., pp. 1623-4.

${ }^{118}$ Ibid., pp. 1769-70.

${ }^{119}$ Ibid., pp. 1526-7; John Craig, 'Reformers, conflict, and revisionism: the Reformation in sixteenth-century Hadleigh', Historical Journal, 42 (1999), pp. 1-23, at pp. 16, 19-20.

${ }^{120}$ Dasent, ed., Acts of the privy council, IV, p. 359.

${ }^{121}$ Suffolk Record Office (Ipswich Branch), C/3/3/2/4, fos. 6r, 7v-8r.

${ }^{122}$ Foxe, Actes and monuments (1583), p. 1567.

${ }^{123}$ Ibid., p. 2101.

${ }^{124}$ A plaine and godlye treatise, concernynge the masse (London, 1555), sigs. F8r, G4v-G6v, H1v, citing I Corinthians 13: 3.

${ }^{125}$ Foxe, Actes and monuments (1583), pp. 1768, 1770.

${ }^{126}$ Ibid., p. 2022; TNA, E357/93 (1556-7); E379/94 (1555-6).

${ }^{127}$ See, for example, James E. Oxley, The Reformation in Essex to the death of Mary (Manchester, 1965), ch. 10. 


\section{HERESY AND FORFEITURE}

${ }^{128}$ Duffy, Fires of faith, pp. 115, 119-20, 122, 128, 136-7; Freeman, 'Burning zeal', pp. $174-5,184-5,187-8,191-4$.

${ }^{129}$ Foxe, Actes and monuments (1563), p. 1607; Nichols, ed., Narratives of the Reformation, pp. $211-12$.

${ }^{130}$ Loades, Religious culture, pp. 142-3.

${ }^{131}$ Janet Cooper, ed., A history of the county of Essex, IX: The borough of Colchester

(Victoria County History, Oxford, 1994), pp. 122-3.

${ }^{132}$ British Library (BL), Stowe MS 829, fos. 24r-v, 32r; Essex Record Office (ERO), D/B 5 Cr121, rot. 6; Foxe, Actes and monuments (1583), p. 2006.

${ }^{133}$ TNA, C89/6/6.

134 TNA, E368/339, precepta, rot. 2ff (Brocket's petition for costs); Foxe, Actes and monuments (1583), pp. 1538-9, 1542-3; Dasent, ed., Acts of the privy council, v, p. 104.

135 TNA, C266/68/14. This document is cited under a previous reference in Gina Alexander, 'Bonner and the Marian persecutions', in Christopher Haigh, ed., The English Reformation revised (Cambridge, 1987), p. 165 n. 33.

${ }^{136}$ TNA, C142/102/53, 66; C142/107/48(2).

${ }^{137}$ Joseph Henry Tyrrell, A genealogical history of the Tyrrells (privately printed, 1904; reprinted London and Chichester, 1980), pp. 115-18; Bindoff, History of parliament, I, pp. 516-18, III, pp. 498-9.

${ }^{138}$ Foxe, Actes and monuments (1583), pp. 1539-42; TNA, C85/127/4-5.

${ }^{139}$ Calendar of the patent rolls, 1553-1554 (London, 1937), pp. 394-5; Calendar of the patent rolls, 1557-1558 (London, 1939), p. 450.

${ }^{140}$ BL, Egerton MS 2949, fos. 106v, 110r-v, 189v-190r, 416r; ERO, D/DU 40/78/1, mm. 34; Foxe, Actes and monuments (1583), pp. 1895-6.

${ }^{141}$ TNA, E368/338, recorda, Michaelmas, rot. 104; ERO, D/DS 494/1-2. 
${ }^{142}$ TNA, C142/102/53.

${ }^{143}$ Loades, 'Essex inquisitions', pp. 87-97; Cavill, 'Essex inquisitions'.

144 TNA, E387/2/80-3; E368/341, brevia retornabilia, Michaelmas.

145 TNA, C85/127/4-5, 8-9, 18, 20.

146 TNA, E387/2/85.

${ }^{147}$ Joel Samaha, Law and order in historical perspective: the case of Elizabethan Essex (New York and London, 1974), p. 65.

${ }^{148}$ Foxe, Actes and monuments (1583), p. 1594.

${ }^{149}$ TNA, C85/127/8; ERO, D/DP M904, rots. 1d-2, 14, 14d, 15d; D/DP M905, rot. 15d; Foxe, Actes and monuments (1583), pp. 1594-6.

${ }^{150}$ Foxe, Actes and monuments (1583), p. 1596; Brett Usher, 'Essex evangelicals under Edward VI: Richard Lord Rich, Richard Alvey and their circle', in David Loades, ed., John Foxe at home and abroad (Aldershot, 2004), pp. 51-61.

${ }^{151}$ ERO, D/DMb M58, rots. 2d, 4-4d, 7; TNA, C85/127/24; Foxe, Actes and monuments (1583), pp. 1971-4, 2005-9.

152 TNA, E150/328/8-9; E357/65 (1554-5).

${ }^{153}$ Dasent, ed., Acts of the privy council, IV, p. 427.

${ }^{154}$ Foxe, Actes and monuments (1563), p. 1605; Thomas Freeman, 'Dissenters from a dissenting church: the challenge of the freewillers, 1550-1558', in Peter Marshall and Alec Ryrie, eds., The beginnings of English Protestantism (Cambridge, 2002), pp. 139-40.

155 TNA, C66/900, m. 26 (Calendar of the patent rolls, 1555-1557, pp. 101-2).

${ }^{156}$ TNA, E368/338, recorda, Michaelmas, rots. 82-3; Trinity, rot. 41; E368/352, status et visus compotorum, Michaelmas, rot. 1.

${ }^{157}$ ERO, D/DU 40/78/1, m. 2; BL, Egerton MS 2949, fos. 187r-v, 272v-273r, 325v, 493r-v; Add. MS 24782, fos. 176r-177v. 


\section{HERESY AND FORFEITURE}

${ }^{158}$ Loach, Parliament and the crown, pp. 138-43.

159 TNA, E368/338, recorda, Michaelmas, rot. 83.

${ }^{160}$ BL, Add. MS 24782, fos. 177v-178v; Egerton MS 2949, fos. 96r, 118r-v, 146v-147r, 187r-v, 411r-412r, 567r-v, 655r-658r; TNA, E150/328/3.

${ }^{161}$ Barbara Peardon, 'The politics of polemic: John Ponet's Short treatise of politic power and contemporary circumstance, 1553-1556', Journal of British Studies, 22, 1 (1982), pp. 35-49, at pp. 42-5.

162 TNA, SP12/125, fo. 114 r.

163 TNA, C4/165/85. I have been unable to trace this case further.

${ }^{164}$ Loades, Religious culture, pp. 118-19.

165 Statutes of the realm (11 vols., London, 1810-28), IV, pp. xxiii ff.

${ }^{166}$ Hilda E. P. Grieve, 'The deprived married clergy in Essex, 1553-1561', Transactions of the Royal Historical Society, 4th ser., 22 (1940), pp. 141-69, at pp. 161-7.

${ }^{167}$ Norman L. Jones, 'Profiting from religious reform: the land rush of 1559', Historical Journal, 22 (1979), pp. 279-94, at pp. 289, 292-4; idem, Faith by statute: parliament and the settlement of religion, 1559 (London, 1982), pp. 103-13, 155-7.

${ }^{168}$ Journals of the House of Commons, I: 1547-1629 (n. p., n. d.), pp. 57, 60; Journals of the House of Lords, I: 1509-1577 (n. p., n. d.), p. 577; TNA, REQ2/36/52; STAC7/5/18; C4/165/34; C78/27/17; Gina Alexander, 'Bishop Bonner and the parliament of 1559', Bulletin of the Institute of Historical Research, 56 (1983), pp. 164-79, at pp. 171-8. ${ }^{169}$ A. S. Gratwick and Christopher Whittick, "The Loseley list of "Sussex martyrs": a commission of enquiry into the fate of their assets and the development of the Sussex Protestant martyrology', Sussex Archaeological Collections, 133 (1995), pp. 225-40, at pp. $235-7$. 


\section{P. R. CAVILL}

${ }^{170}$ John Baker, ed., Baker and Milsom: sources of English legal history: private law to 1750 (2nd edn, Oxford, 2010), pp. 142-4.

${ }^{171}$ N. G. Jones, 'The influence of revenue considerations upon the remedial practice of chancery in trust cases, 1536-1660', in Christopher Brooks and Michael Lobban, eds., Communities and courts in Britain, 1150-1900 (London, 1997), pp. 99-113.

${ }^{172}$ TNA, C78/18/36. I owe this reference to Jones, 'Trusts in England', p. 185 n. 78.

${ }^{173}$ Garrett, Marian exiles, p. 197; Foxe, Actes and monuments (1563), p. 1605.

${ }^{174}$ TNA, C3/32/79.

175 TNA, C3/196/36; C33/31, fos. 429v, 488r; C33/32, fos. 235v, 423r; William Berry, County genealogies: pedigrees of the families in the county of Sussex (London, 1830), p. 181. ${ }^{176}$ Robert Tittler, Nicholas Bacon: the making of a Tudor statesman (London, 1976), p. 54. ${ }^{177}$ Foxe, Actes and monuments (1583), p. 1979; John Strype, Annals of the Reformation (4 vols. in 7 pts., Oxford, 1824), I, i, pp. 558-9; TNA, C33/27, fo. 362r; C33/28, fo. 372r; Thomas Freeman, 'Notes on a source for John Foxe's account of the Marian persecution in Kent and Sussex', Historical Research, 67 (1994), pp. 203-11, at pp. 204, 206.

${ }^{178}$ BL, Hargrave MS 9, fo. 174r.

179 John Baker, The Oxford history of the laws of England, vI: 1483-1558 (Oxford, 2003), pp. $77-8$.

180 TNA, C142/117/35; E379/94 (1555-6); REQ2/270/50; BL, Stowe Charters 402-3.

${ }^{181}$ Pettegree, Marian Protestantism, ch. 6.

${ }^{182}$ Shagan, Popular politics, pp. 12-25.

${ }^{183}$ The classic statement is E. P. Thompson, Whigs and hunters: the origin of the Black Act (London, 1975), ch. 10. 


\section{HERESY AND FORFEITURE}

${ }^{184} 13$ Eliz. I, c. 3; 14 Eliz. I, c. 6; 29 Eliz. I, c. 6; Jennifer Loach, Parliament under the Tudors (Oxford, 1991), pp. 83-4, 112-14; Charles Ross, Elizabethan literature and the law of fraudulent conveyance: Sidney, Spenser, and Shakespeare (Aldershot, 2003), ch. 2.

${ }^{185}$ N. G. Jones, ‘Trusts: practice and doctrine, 1536-1660’ (Ph.D. thesis, Cambridge, 1994), pp. 269-91, summarized in Jones, 'Trusts in England', pp. 185-6.

186 Thomas S. Freeman, 'Introduction: over their dead bodies: concepts of martyrdom in latemedieval and early-modern England', in Thomas S. Freeman and Thomas F. Mayer, eds., Martyrs and martyrdom in England, c.1400-1700 (Woodbridge, 2007), pp. 26-31.

${ }^{187}$ Gabriel Glickman, 'Early modern England: persecution, martyrdom - and toleration?', Historical Journal, 51 (2008), pp. 251-67. 